\title{
Front Matter: Volume 8245
}

, "Front Matter: Volume 8245," Proc. SPIE 8245, Synthesis and Photonics of Nanoscale Materials IX, 824501 (9 March 2012); doi: 10.1117/12.930896

SPIE. Event: SPIE LASE, 2012, San Francisco, California, United States 


\title{
PROCEEDINGS OF SPIE
}

\section{Synthesis and Photonics of Nanoscale Materials IX}

\author{
Frank Träger \\ Jan J. Dubowski \\ David B. Geohegan \\ Editors
}

23-24 January 2012

San Francisco, California, United States

Sponsored and Published by

SPIE 
The papers included in this volume were part of the technical conference cited on the cover and title page. Papers were selected and subject to review by the editors and conference program committee. Some conference presentations may not be available for publication. The papers published in these proceedings reflect the work and thoughts of the authors and are published herein as submitted. The publisher is not responsible for the validity of the information or for any outcomes resulting from reliance thereon.

Please use the following format to cite material from this book:

Author(s), "Title of Paper," in Synthesis and Photonics of Nanoscale Materials IX, edited by Frank Träger, Jan J. Dubowski, David B. Geohegan, Proceedings of SPIE Vol. 8245 (SPIE, Bellingham, WA, 2012) Article CID Number.

ISSN 0277-786X

ISBN 9780819488886

Published by

SPIE

P.O. Box 10, Bellingham, Washington 98227-0010 USA

Telephone +1 3606763290 (Pacific Time) · Fax +1 3606471445

SPIE.org

Copyright (C) 2012, Society of Photo-Optical Instrumentation Engineers

Copying of material in this book for internal or personal use, or for the internal or personal use of specific clients, beyond the fair use provisions granted by the U.S. Copyright Law is authorized by SPIE subject to payment of copying fees. The Transactional Reporting Service base fee for this volume is $\$ 18.00$ per article (or portion thereof), which should be paid directly to the Copyright Clearance Center (CCC), 222 Rosewood Drive, Danvers, MA 01923. Payment may also be made electronically through CCC Online at copyright.com. Other copying for republication, resale, advertising or promotion, or any form of systematic or multiple reproduction of any material in this book is prohibited except with permission in writing from the publisher. The CCC fee code is 0277-786X/12/\$18.00.

Printed in the United States of America.

Publication of record for individual papers is online in the SPIE Digital Library.



SPIEDigitalLibrary.org

Paper Numbering: Proceedings of SPIE follow an e-First publication model, with papers published first online and then in print and on CD-ROM. Papers are published as they are submitted and meet publication criteria. A unique, consistent, permanent citation identifier (CID) number is assigned to each article at the time of the first publication. Utilization of CIDs allows articles to be fully citable as soon as they are published online, and connects the same identifier to all online, print, and electronic versions of the publication. SPIE uses a six-digit CID article numbering system in which:

- The first four digits correspond to the SPIE volume number.

- The last two digits indicate publication order within the volume using a Base 36 numbering system employing both numerals and letters. These two-number sets start with 00, 01, 02, 03, 04, $05,06,07,08,09,0 A, 0 B \ldots 0 Z$, followed by 10-1Z, 20-2Z, etc.

The CID number appears on each page of the manuscript. The complete citation is used on the first page, and an abbreviated version on subsequent pages. Numbers in the index correspond to the last two digits of the six-digit CID number. 


\section{Contents}

$\checkmark$ Conference Committee

\section{SESSION 1 FRONTIERS IN PLASMONICS}

824504 Dynamics of two-photon photoluminescence in gold nanostructures [8245-03]

P. Biagioni, CNISM, Politecnico di Milano (Italy); D. Brida, IFN, CNR, Politecnico di Milano (Italy); J.-S. Huang, National Tsing-Hua Univ. (Taiwan); J. Kern, Julius-Maximilians-Univ. Würzburg (Germany); L. Duò, CNISM, Politecnico di Milano (Italy); B. Hecht, Julius-Maximilians-Univ. Würzburg (Germany); M. Finazzi, CNISM, Politecnico di Milano (Italy);

G. Cerullo, IFN, CNR, Politecnico di Milano (Italy)

\section{SESSION 2 NANOPARTICLE SYNTHESIS AND APPLICATIONS}

824507 Noble metal nanoparticles on quartz supports as SERS substrates excited by a diode laser system for SERDS [8245-17]

R. Ossig, Univ. Kassel (Germany); Y.-H. Kwon, Technische Univ. Berlin (Germany) and Institute of Lasers (Korea, Democratic Peoples Republic of); H.-D. Kronfeldt, Technische Univ. Berlin (Germany); F. Träger, F. Hubenthal, Univ. Kassel (Germany)

\section{SESSION 3 GRAPHENE AND CARBON NANOTUBES}

8245 OC Femtosecond laser-assisted photobleaching of single-wall carbon nanotubes [8245-1 1] S. Shoji, H. Kobayashi, T. Rodgers, Osaka Univ. (Japan); S. Kawata, Osaka Univ. (Japan), RIKEN (Japan), and Japan Corp. of Science and Technology (Japan)

SESSION 4 LASER NANOSCALE MATERIALS PROCESSING AND MANUFACTURING: JOINT SESSION WITH CONFERENCE 8243

8245 OE XPS study of InP/InGaAs/InGaAsP microstructures irradiated with ArF laser in air and deionized water [8245-13]

N. Liu, K. Moumanis, S. Blais, J. J. Dubowski, Univ. de Sherbrooke (Canada)

\section{SESSION 5 NANOPARTICLE CHARACTERIZATION AND BIOLOGICAL APPLICATIONS}

$8245 \mathrm{OH}$ Exploring exciton-plasmon coupling in laser- and electron-beam-fabricated nanostructures (Invited Paper) [8245-16]

B. J. Lawrie, Vanderbilt Univ. (United States); R. Mu, Fisk Univ. (United States);

R. F. Haglund, Jr., Vanderbilt Univ. (United States) 
8245 OK Influence of the growing parameters on the size distribution of PbTe nanoparticles produced by laser ablation under inert gas atmosphere [8245-20]

D. B. Almeida, Univ. Estadual de Campinas (Brazil); E. Rodriguez, Instituto Politécnico Nacional (Mexico); S. Agouram, Univ. de Valencia (Spain); R. S. Moreira, C. L. Cesar, Univ. Estadual de Campinas (Brazil); E. Jimenez, Univ. de Valencia (Spain); L. C. Barbosa, Univ. Estadual de Campinas (Brazil)

POSTER SESSION

$8245 \mathrm{OL}$ Femtosecond and picosecond ablation of aluminum for synthesis of nanoparticles and nanostructures and their optical characterization [8245-21]

S. Hamad, G. K. Podagatlapalli, S. Sreedhar, S. P. Tewari, S. Venugopal Rao, Univ. of Hyderabad (India)

$8245 \mathrm{ON}$ Influence of $\mathrm{ZnO}$ buffer layer on $\mathrm{ZnO}$ nanowire growth by nanoparticle-assisted pulsed laser deposition [8245-23]

D. Nakamura, T. Shimogaki, K. Okazaki, I. A. Palani, K. Kubo, K. Tsuta, M. Higashihata,

T. Okada, Kyushu Univ. (Japan)

$8245 \mathrm{OP} \quad$ Novel beam splitter for high-order harmonics with $\mathrm{WO}_{3} / \mathrm{TiO}_{2}$ bilayer grown on c-plane sapphire substrate by sequential surface chemical reactions [8245-25]

Y. Sanjo, M. Murata, H. Kumagai, Osaka City Univ. (Japan); Y. Nabekawa, K. Midorikawa, RIKEN (Japan); M. Chigane, Osaka Municipal Technical Research Institute (Japan)

Author Index 


\title{
Conference Committee
}

\author{
Symposium Chairs
}

Friedhelm Dorsch, TRUMPF Werkzeugmaschinen GmbH + Co. KG (Germany)

Alberto Piqué, Naval Research Laboratory (United States)

Symposium Cochairs

Bo Gu, IPG Photonics Corporation (China)

Andreas Tünnermann, Friedrich-Schiller-Universität Jena (Germany)

Program Track Chairs

Henry Helvajian, The Aerospace Corporation (United States)

James S. Horwitz, U.S. Department of Energy (United States)

Conference Chairs

Frank Träger, Universität Kassel (Germany)

Jan J. Dubowski, Université de Sherbrooke (Canada)

David B. Geohegan, Oak Ridge National Laboratory (United States)

\section{Program Committee}

Carmen N. Afonso, Consejo Superior de Investigaciones Científicas (Spain)

Paolo Biagioni, Politecnico di Milano (Italy)

J. Thomas Dickinson, Washington State University (United States)

Haim Grebel, New Jersey Institute of Technology (United States)

Costas P. Grigoropoulos, University of California, Berkeley (United States)

Tony F. Heinz, Columbia University (United States)

Ilko K. Ilev, U.S. Food and Drug Administration (United States)

Hiroshi Kumagai, Osaka City University (Japan)

Thomas K. Lippert, Paul Scherrer Institut (Switzerland)

Vladimir M. Shalaev, Purdue University (United States)

Xianfan Xu, Purdue University (United States)

Yaqiong $X u$, Vanderbilt University (United States) 
Session Chairs

1 Frontiers in Plasmonics

Frank Träger, Universität Kassel (Germany)

2 Nanoparticle Synthesis and Applications

Jan J. Dubowski, Université de Sherbrooke (Canada)

3 Graphene and Carbon Nanotubes

David B. Geohegan, Oak Ridge National Laboratory (United States)

4 Laser Nanoscale Materials Processing and Manufacturing: Joint

Session with Conference 8243

Richard F. Haglund, Jr., Vanderbilt University (United States)

5 Nanoparticle Characterization and Biological Applications

Frank Hubenthal, Universität Kassel (Germany) 